\title{
Relationship Between Health Behavior and Quality of Life of the Elderly
}

\author{
$1^{\text {st }}$ Fitria Lestari \\ Midwifery Study Program \\ AkademiKebidanan Prima Husada Bogor \\ Bogor, Indonesia \\ fitrialestari1788@yahoo.co.id.com
}

\author{
$2^{\text {nd }}$ Lela Zakiah \\ Midwifery Study Program \\ AkademiKebidanan Prima Husada Bogor \\ Bogor, Indonesia \\ lelazakiah07@gmail.com
}

\begin{abstract}
The increasing number of elderly will require serious treatment for the elderly naturally decline, physical, biological, and mental. People, especially the elderly in PasirMulya have bad habits in terms of preparing food, eating food, such as frequently eating fast food. To analyze the relationship between health behavior and quality of life of the elderly. Quantitative approach to the cross-sectional design. Population of 92 elderly people with samples taken using total sampling technique. Statistically using Chi Square test and Multiple Logistic Regression. There were elderly people who have a poor quality of life in health centers PasirMulya, Bogor as much as $62 \%, 63 \%$ of young elderly age, female gender $68.5 \%, 69.6 \%$ lower education, employment (not working) $\mathbf{5 4 . 3 \%}$ consumption of foods that are not varied $56.5 \%, 58.7 \%$ smoking habits, physical activity / exercise irregular $66.3 \%, 55.4 \%$ negarif attitude, $60.9 \%$ less knowledge, and behaviors related to Sundanese culture less appreciate by $\mathbf{5 9 . 8 \%}$. Variables significantly associated with quality of life of the elderly that is age, gender, education, employment, food consumption, smoking habits, physical activity / exercise, attitudes, knowledge and behavior related Sundanese culture. $(P<0.05)$. Education is the dominant variables relating to the quality of life of elderly $(O R=83.213)$ means the elderly are highly educated have a chance 83 times to live with a good quality compared to the elderly who have low education.
\end{abstract}

\section{Keywords-Elderly, physical activity, Sundanese culture}

\section{INTRODUCTION}

More elderly populations around the world are going very fast compared to other age groups. However, what is referred to as the "Elderly Era" [1]. It is estimated that the growth of the proportion of the elderly from 2000-2025 has doubled worldwide, from 606 million (10\% of the total world population) to 1.2 billion. This number will reach around 2 billion, $22 \%$ of the world population in $2050^{[2]}$.

The increase in elderly population growth began to be felt since 2000, namely the number of elderly 14.4 million people with an increase of $7.18 \%$ with a life expectancy of 64.5 years, in 2006 the number of elderly 19 million people with an increase of about $8.9 \%$ with a life expectancy of 66.2 years. In 2010 the elderly population is estimated at 23.9 million people with an increase of $9.7 \%$ with a life expectancy of 67.4 years. It is estimated that in 2020 the number of elderly people in Indonesia will reach 28.8 million with an increase of about $11.34 \%$ and life expectancy of 71.1 years. It is estimated that in 2020-2025 Indonesia will be ranked fourth in the world under China, India, and the United States ${ }^{[3]}$
Life expectancy estimates in each province in Indonesia have increased. In the period 2000-2005, 20052010 and 2010-2015, in Jakarta 73 years, 74 years and 75.4 years. Life expectancy in West Java is 66.6 years, 69.0 years and 70.9 years. Kalimantan Island also experienced the largest increase in East Kalimantan, namely 69.6 years, 71.6 years and 73.1 years ${ }^{[1] .}$

In West Java, the number of elderly population in 2010 reached more than 3.44 million or around $8.01 \%$ of the total population of West Java which reached 43 million people (West Java Provincial Government). the projected population above the age of 45 years in 2000 $(6,456,400$ people), 2005 (7,845,700 people) and 2010 $(9,600,300$ people) [1]. This reflects advances in technology and information, especially about health, which makes people aware of healthy living. At the same time there are obstacles to living longer, given the inevitable aging process. Many factors are affected by years of exposure to risk factors.

Health behavior is a determinant of health in the elderly group. Several factors such as diet, smoking, sports activities and periodic examinations are determinations that can free the elderly from chronic diseases. The elderly who exercise regularly will look more productive and avoid chronic diseases and compensate, thereby reducing health costs with social care. Increased physical activity such as sports activities and reduction in smoking will reduce the risk of coronary heart disease. Increasing the functional ability can prevent many negative processes of aging and help increase independence ${ }^{[4]}$.

The increase in the elderly population has various implications, namely socio-cultural, economic and health aspects. Health aspects show changes in disease patterns. Socio-cultural aspects, each tribe has differences in land affairs, specifically in terms of economic assistance. Elderly people who are not working need support from others in economic matters. The family is the closest to their social environment. While girls are equal to boys, they are busy at work, so the elderly accept homes that are willing to care for them.

To overcome these problems, the concept approach of healthy elderly and active elderly can be done to improve physical health. This does not prevent aging but reduces the psychosocial burden, stress and depression and prevents the severity of chronic diseases. This study aims to analyze the relationship between healthy behavior and 
quality of life in the elderly in Posbindu Work Area, Puskesmas Pasir Mulya Bogor 2016.

\section{METHOD}

This research is a cross sectional research with quantitative research type. This research was conducted in Posbindu Working Area of Puskesmas Pasir Mulya Bogor in 2016 in November - February 2017. The population was 92 elderly people and all of them were used as samples. The research instrument to measure the quality of life of the elderly uses the WHOQOL standard instrument while the Sundanese cultural aspects uses an instrument developed by the researcher. The data collection technique of this research is to use data collected in this study using primary data obtained directly from respondents by filling out a questionnaire that is guided directly by an enumerator (data collection). The data of this study were taken by researchers and assisted by Postgraduate Public Health Sciences students and Posbindu Cadres in Puskesmas Pasir Mulya Bogor Work Area. which had previously been done apresepsi. Data and information collected were analyzed in stages through univariate analysis, bivariate analysis (Chi Square) and multivariate (multiple logistic regression).

\section{RESULT AND DISCUSSTION}

Multivariate Analysis

*p value $>0,05$ excluded from modeling

\begin{tabular}{|l|l|l|l|}
\hline \multicolumn{1}{|c|}{ Variable } & P value & OR & $(95 \% \mathrm{CI})$ \\
\hline Education & 0.003 & 83.213 & $4.489-1542.525$ \\
\hline Behavior & 0.011 & 10.134 & $1.688-60.836$ \\
\hline Age & 0.019 & 9.444 & $1.443-61.803$ \\
\hline Attitude & 0.020 & 7,820 & $1.378-44.371$ \\
\hline Gender & 0.034 & 5.606 & $1.142-27.517$ \\
\hline
\end{tabular}

\begin{tabular}{|l|c|c|c|}
\hline Variable & $P$ value & OR & $(95 \% \mathrm{CI})$ \\
\hline Age & 0,019 & 9,444 & $1,443-61-803$ \\
\hline Gender & 0,034 & 5,606 & $1,142-27,517$ \\
\hline Education & 0,003 & 83,213 & $4,489-1542,525$ \\
\hline Occupaation & 0,104 & 5,351 & $0,707-40,473$ \\
\hline $\begin{array}{l}\text { food } \\
\text { consumption }\end{array}$ & 0,185 & 3,419 & $0,554-21,097$ \\
\hline $\begin{array}{l}\text { Ettitude } \\
\text { Knowledge }\end{array}$ & 0,020 & 7,820 & $1,378-44,371$ \\
\hline Behavior & 0,011 & 10,134 & $1,688-60,836$ \\
\hline $\begin{array}{l}\text { Physical } \\
\text { Activity }\end{array}$ & 0,876 & 0,864 & $0,138-5,414$ \\
\hline
\end{tabular}

Based on research from 92 elderly people studied, who have a poor quality of life was greater in the middle aged age group (70-79 years) by $(82.4 \%)$. Statistical test results of the relationship between age and quality of life of the elderly obtained $\mathrm{p}$ value 0.004 , this means that there is a significant relationship between age and quality of life of the elderly with an OR $=4,667$. This is in accordance with research conducted by ${ }^{[5]}$ in Sleman Regency stating that age factors in research subjects show a very weak and negative patterned relationship meaning that the older the age the worse the quality of life because the quality of life of the elderly tends to decrease with age.

Based on those who have poor quality of life, it turns out that it is greater in the elderly group with female sex (76.2\%) compared. Statistical test results of the relationship between sex with the quality of life of the elderly obtained $p$ value 0,000 , this means that there is a significant relationship between sex with the quality of life of the elderly with the results of $\mathrm{OR}=7,111$. This is according to research conducted by ${ }^{[5]}$ in Sleman Regency stating that the relationship between quality of life with gender factors shows a weak and negative patterned relationship meaning that women have a worse quality of life compared to men $(r=0.126)$.

Based on those who have poor quality of life, it turns out to be greater in the elderly group who have low education by $(75 \%)$. Statistical test results of the relationship between education and quality of life of the elderly obtained $p$ value 0,000 , this means that there is a meaningful relationship between education and quality of life of the elderly with the results of $\mathrm{OR}=6.333$. This is in accordance with research conducted by ${ }^{[6]}$ stating that education will affect the patterns of behavior in daily life, including eating patterns, perspectives on healthy living and their access to health services in the elderly.

Based on those who have poor quality of life, it turns out to be greater in the elderly group who do not work by $(76 \%)$. Statistical test results of the relationship between work and the quality of life of the elderly obtained $p$ value 0.005 , this means that there is a significant relationship between work with the quality of life of the elderly with the results $\mathrm{OR}=3.833$. This is consistent with research conducted by [7] regarding the effect of work on the quality of life of the elderly ( $p$ value $0.002<0.05$ ). Most of the elderly who are not active as housewives (not working) are 21 elderly (69.3\%). While those who work get a good quality of life because by working they have more income that can be used to improve the quality of life in terms of consuming food, the elderly has mental and physical activities that make themselves feel happier.

Based on studies that have poor quality of life, it turns out to be greater in the elderly group whose food consumption does not vary by $(76.9 \%)$. Statistical test results of the relationship between work with the quality of life of the elderly obtained $p$ value 0.002 , this means that there is a significant relationship between the elderly who consume food that does not vary with the quality of life of the elderly with an $\mathrm{OR}=4,510$. This is consistent with research conducted by ${ }^{[8]}$ in Sleman Regency stating that the relationship between quality of life with food type factors in the statistical test results found that there is a significant relationship between food consumed and quality of life $(\mathrm{P}$ value $=0.001)$.

Based on those who have poor quality of life, it turns out to be greater in the elderly group who smoke (75.9\%). The statistical test results obtained $p$ value 0.002 , so it can be concluded that there is a significant relationship between smoking habits with the quality of life of the 
elderly with the results of $\mathrm{OR}=4.337$. Based on the results of observations made while conducting research in the Work Area of Puskesmas Pasir Mulya, it was found several elderly women who were still smoking.

Based on those who have poor quality of life, it turns out to be greater in the elderly group who do not regularly do physical / sports activities $(72.1 \%)$. The statistical test results obtained $\mathrm{p}$ value of 0.010 , it can be concluded that there is a significant relationship between physical activity / sports with the quality of life of the elderly with the results of $\mathrm{OR}=3,584$. This is consistent with the results of a survey conducted by the Republic of Indonesia Ministry of Health which showed that around $90 \%$ of the elderly have a low level of physical fitness, especially in the endurance component of cardio-respiration and muscle strength.

Based on those who have poor quality of life, it turns out to be greater in the elderly group who have a negative attitude $(86.3 \%)$. The statistical test results obtained $\mathrm{p}$ value of 0,000 , it can be concluded that there is a significant relationship between attitude and quality of life of the elderly with the results of $\mathrm{OR}=13,538$. This is consistent with the results of this study in line with research by Hesthi (2010) that there is a significant relationship between attitude and quality of life of the elderly $(\mathrm{p}=0.001)$.

Based on those who have poor quality of life, it turns out to be greater in the elderly group with less knowledge $(76.8 \%)$. The statistical test results obtained $\mathrm{p}$ value of 0.001 , it can be concluded that there is a significant relationship between knowledge with the quality of life of the elderly with the results of OR $=5.198$. The results of this study are in line with the study of [9] that there is a significant relationship between knowledge and quality of life for the elderly $(\mathrm{p}=0.019)$.

Based on those who have poor quality of life, it turns out to be greater in the group of elderly people who do not appreciate Sundanese culture (78.2\%). Statistical test results obtained $p$ value of 0,000 , so it can be concluded that there is a significant relationship between Sundanese culture-related behavior with the quality of life of the elderly with the results of $\mathrm{OR}=5.887$. Statistical test results obtained $\mathrm{p}$ value $0,000 \mathrm{p}<$ alpha $(0.05)$ means that there is a relationship between culture and the quality of life of the elderly, with OR $=26,400$ which shows that the elderly who still behave in harmony with Javanese philosophy and cultural traditions have the opportunity to have a good quality of life of the elderly by 26,4 times compared with the elderly who do not behave in harmony with Javanese philosophy and tradition.

From the results of the last multivariate modeling analysis it is known that the age variable is obtained $p$ value $0.019(<0.05)$, gender is obtained $\mathrm{p}$ value 0.034 $(<0.05)$, education is obtained $\mathrm{p}$ value $0.003 \quad(<0.05)$, attitudes are obtained p value of $0.020(<0.05)$, Sundanese culture related behavior obtained $\mathrm{p}$ value of $0.011(<0.05)$, so it can be concluded that there is a relationship between age, sex, education, attitudes, and behavior related to Sundanese culture with quality living elderly. While physical activity / sports variables obtained $p$ value 0.876
(> 0.05), knowledge obtained p value 0.407 (>0.05), food consumption obtained $\mathrm{p}$ value 0.185 ( $>0.05$ ), work obtained $p$ value $0.104(>0.05)$ as a confounding variable.

The results of the analysis note that the dominant variable related to the quality of life of the elderly is the educational variable with an Odds Ratio value of 83.213 meaning that the elderly with high education have 83 times the opportunity to live with good quality compared to the elderly who have low education. Higher education teaches people to think more logically and rationally, to be able to see an issue from various sides so that they can do more analysis and solve a problem. In addition, higher education improves cognitive skills needed to be able to continue learning outside of school.

\section{CONCLUSIONS AND SUGGESTIONS}

$62 \%$ of elderly people in the PasirMulya district of Bogor have a poor quality of life. For the development of the Elderly Health Program in Posbindu the working area of PuskesmasPasirMulya needs to be done. Educational programs in the elderly should be carried out more comprehensively and taught according to the material available and relevant to the times, and should be held or fostered by people who are competent in the fields of caring for the elderly and competent in the experts. Providing counseling or approaching health workers as well as religious leaders or community leaders by taking into account cultural values in social life, especially in the elderly posyandu programs including those related to health, social life, friendship, mutual respect and spiritual. In an effort to improve the quality of life of elderly women, their health status must be improved, reducing strenuous activities, and hormonal improvements by establishing a menopause clinic. Provide motivation and information for the elderly, especially middle aged and elderly elderly to improve a better quality of life.

\section{ACKNOWLAGMENT}

This research supported by AkademiKebidanan Prima Husada Bogor

\section{REFERENCES}

[1] BadanPusatStatistik, Bappenas, UNFPA. 2005. Proyeksi Penduduk Indonesia 2000-2025.Badan Pusat Statistik, Jakarta.

[2] United Nations. (2003). Laporan Perkembangan Pencapaian Tujuan Pembangunan Milenium Indonesia.

[3] Nugroho, Wahjudi, (2008). Keperawatan Gerontik dan Geriatri (Edisi 3). Jakarta: EGC.

[4] Handajani, Yvonne Suzy. (2006). Indeks Pengukuran Disabilitas dan Prediksi Kualitas Hidup Pada Masyarakat Lanjut Usia di DKI Jakarta (Suatu Upaya Memperkirakan Kemandirian Lanjut Usia).

[5] Nurhasanah, dkk. (2009). Hubungan Tingkat Depresi Dengan Kulaitas Hidup Pada Masyarakat Daerah Bencana Pasca Gempa Bumi di kabupaten Sleman Tahun 2008. Berita Kedokteran Masyarakat, Vol.25, No.1, Maret 2009.

[6] Sugiharti. (2010). PerawatanLanjutusia. EdisiKedua. Jakarta: EGC.

[7] Rosyid, Fahrun Nur, dkk. 2009. Faktor-faktor yang Mempengaruhi Kunjungan Lansia ke Posyandu Lansia di RW VII Kelurahan Wonokusumo Kecamatan Semampir Surabaya. Surabaya: Universitas Muhammadiyah Surabaya

[8] Rusilanti, K. 2006. Model Hubungan Aspek Psikososial dan Aktivitas Fisik dengan Pola makan Lansia. Jakarta: Jurnal Gizi dan Pangan edisi Juli 2006. 
[9] [9] Dwi Sapta Aryantiningsih.Faktor-faktor yang Berhubungan dengan Pemanfaatan Posyandu Lansia di Kota Pekanbaru. 2014; Vol. 1:42-7.

[10] Detik news. 2011. https://m.detik.com/news/jawabarat/165567/8persen-penduduk-jawa-barat-adalah-lansia.diakses pada tanggal 17 Februari 2017 jam 11.26.

[11] Departemen Kesehatan RI. (2006). Status Kesehatan, Pelayanan kesehatan, Perilaku Hidup Sehat dan Kesehatan Lingkungan.Survei Kesehatan Nasional 2004.

[12] Endah Tri Wahyuni, 2016.

[13] Gail W. Stuart, alih bahasaAchir S. Hamid, 2006. Buku Saku Keperawatan Jiwa, Edisi 3 Jakarta: EGC

[14] Wahono, Hesti. 2010. Analisa Factor-Faktor Yang Mempengaruhi Pemanfaatan Posyandu Lansia Di Gantungan Makam haji. Skripsi.Tidak diterbitkan. Surakarta: Keperawatan S1 Fakultas ilmu kesehatan UMS.

[15] Sulistiarini, (2018). Hubungan Perilaku Hidup Sehat Dengan Status Kesehatan Pada Masyarakat. https://www.researchgate.net/publication/328286431_HUBUNGA N_PERILAKU_HIDUP_SEHAT_DENGAN_STATUS_KESEH ATAN_PADA_MASYARAKAT_KELURAHAN_UJUNG

[16] Stefanus, MK (2018). Peningkatan Kualitas Hidup Lanjut Usia Di Kota Depok Dengan Latihan Keseimbangan. http://jki.ui.ac.id/index.php/jki/article/view/584 